\title{
Effectiveness of Goji Berries (Lycium barbarum) Extract and Some Nanoparticles Loaded on Gelatin Film on Microbial Content of Labneh
}

\author{
${ }^{1}$ Oroba Bahjat Shihab, ${ }^{1}$ Mohammed Ahmed Jassim, ${ }^{2}$ Hashim Mohammed Zehraw* \\ ${ }^{1}$ Department of Food Science, College of Agriculture, Tikrit University - Iraq \\ ${ }^{2}$ Abn Albetar Center/ Corporation of Research and Industrial Development - Iraq
}

\section{Article information}

\section{Article history:}

Received: April, 04, 2021

Accepted: June, 12, 2021

Available online: December, 14, 2021

\section{Keywords:}

Nanotitanium,

Lycium barbarum,

Goji Berries,

Labneh,

Nanochitosan

*Corresponding Author:

Hashim Mohammed Zehraw

hzehraw@gmail.com

DOI:

https://doi.org/10.53523/ijoirVol8I3ID33

\begin{abstract}
This study was conducted to evaluate the effect of Lycium barbarum extract, Chitosan nanoparticles (ChNPs) and Nanotitanium dioxide $\left(\mathrm{TiO}_{2} \mathrm{NPs}\right)$ loaded on Gelatin films on the microbial content of labneh during different storage periods. The samples were divided into seven treatments which included (T1) non-coated labneh, (T2) labneh coated with gelatin membranes, (T3) labneh coated with gelatin membranes and Lycium barbarum extract, (T4) labneh coated with gelatin films and ChNPs, (T5) labneh coated with gelatin films treated $\mathrm{TiO}_{2} \mathrm{NPs}$, (T6) Labneh coated with gelatin films, Lycium barbarum and ChNPs, (T7) Labneh coated with gelatin films, Lycium barbarum and $\mathrm{TiO}_{2} \mathrm{NPs}$. The total number of bacteria decreased after loading with the membranes for each specific period of time, and the treatment with $\mathrm{T} 7$ was the best, as the total number of bacteria decreased to $9.93 \mathrm{log} / \mathrm{gm}$ compared to the two controls (T1, T2), which amounted to $(15.58,13.47 \mathrm{log} / \mathrm{gm})$ after 14 days of storage, respectively. While the numbers of Lipolytic and Proteolytic bacteria, yeasts and molds did not show any growth at the time of one day, with the prolonged storage period, the gradual increase in the total count of bacteria occurred for all treatments, it reached the highest numbers at the time of 14 days. Treatment $\mathrm{T} 7$ was the best in reducing the numbers of both lipolytic and proteinolytic bacteria, as well as yeasts and molds.
\end{abstract}

\section{Introduction}

Labneh is a fermented dairy product that is prepared from the concentration of curd by extracting it from a portion of the whey by filtering, it is a type of soft cheese that has a distinct flavor due to the presence of the diacetyl compound produced during the fermentation process. It is common in many countries of the world, especially in the countries of the Middle East, because of its importance at home meals [1]. Given the great importance of labneh due to its richness in essential elements for humans and its role in protecting the intestine from many digestive disorders, many researchers have been interested in studying this product from a microbial aspect. One of the methods used to extend the shelf life of perishable foods is the use of plant extracts and nanoparticles. [2,3]. Some studies confirmed that many of the active substances in medicinal plants were used against microbes to 
ensure their effectiveness, and it was found that some plants have the ability to produce aromatic substances such as phenols, or their derivatives, and most of them are secondary derivatives. Among these plants the Goji berries (GB) plant [4]. Nanotechnology has been applied in the field of food, and the term Nanofood is widely used, which means any food produced or treated at any stage of its production related to its cultivation, processing or rehabilitation using various nanotechnology techniques [5]. And fall under this name those foods that contain additives made of nanomaterials such as nanoparticles of free metal elements of iron and zinc and materials for enzymes that work to operate these enzymes efficiently, as thin layers consisting of some metal oxides such as titanium dioxide $\mathrm{TiO}_{2}$, zinc oxide $\mathrm{ZnO}$, copper oxide $\mathrm{CuO}$ and Chitosan ChNPs for preserving fresh food products such as: meat, fruits, dairy products, sweets, bread, and those layers with a diameter of less than 5 nanometers, extend the shelf life of preserved foods even after opening the package by preventing gases from seeping into the surface of the food and not being affected by moisture and radiation factors that lead to spoilage of food and its pollution, these layers are antioxidant, safe, non-toxic and biocompatible with the human body [6].

\section{Materials and Methods}

Goji Berries Extract (GBE): The extraction was carried out according to the method mentioned by Chan et al. [5], in preparing the alcoholic extract of GB, as (20) $\mathrm{g}$ of GB powder was taken with (200) ml of ethyl alcohol at a concentration of $(100 \%)$ in a conical flask, then transferred to A vibrating water bath at a speed of 250 cycle/ minute at a temperature of $60{ }^{\circ} \mathrm{C}$ for 240 minutes. After that, the extract was filtered using filter paper (Whatman No: 1), then evaporation was carried out using a rotary evaporator to obtain the concentrated extract, then it was dried using the oven at a temperature of $50{ }^{\circ} \mathrm{C}$ for 24 hours. In the form of a dried powder, thus obtaining a solution of concentration $(10) \mathrm{mg} / \mathrm{ml}$.

Nanoparticles: Chitosan nanoparticles equipped from the Chinese company (Trading) were used with the following specifications: purity: $96.27 \%$, viscosity: 25 centipoises, percentage of ash: $0.73 \%$, percentage of moisture: $9.45 \%$, particle size: $26 \mathrm{~nm}$ and density: $0.32 \mathrm{~g} / \mathrm{cm} 2$. white powder. While the titanium dioxide particles equipped by the American company (NANOSHEL), they had the following specifications, purity: $99.1 \%$, the special surface area was greater than $30 \mathrm{~m}^{2} / \mathrm{g}$, the particle size was less than $25-48$ nanometers and the density was $0.3 \mathrm{~g} / \mathrm{cm}^{2}$, which had a laminate appearance in the form of an odorless white powder.

Gelatin Film Preparation: Membrane solutions were prepared according to the De Carvalho and Grosso method, [6] with a weight of $10 \mathrm{~g}$ of gelatin powder, dissolved in $80 \mathrm{ml}$ distilled water and all the ingredients were mixed by using a hot plate magnetic stirrer at $60^{\circ} \mathrm{C}$ for 15 minutes and then $30 \%$ glycerol was added. the dry gelatin was weighed, the volume to $100 \mathrm{ml}$ of distilled water was completed and the $\mathrm{pH}$ to 7 was adjusted, then the extract and the nanoparticles (which were prepared as mentioned in the previous paragraph) were added inside the membrane solution to a vacuum pump for 10 minutes to get rid of air bubbles, and the solution was kept in the refrigerator in dark conditions to prevent the occurrence of operations Oxidative stress.

Pouring and Drying the Film-Forming Solutions: The casting and drying process of the film solutions took place in plastic dishes with an inner diameter of $18 \mathrm{~cm}$, and the volume chosen was $30 \mathrm{ml}$ after carrying out several initial experiments to obtain the appropriate thickness of the membrane, then the solution was spread quietly by moving the plate left and right on a flat and stable surface to ensure uniform distribution over the area of the plate, then the dishes were dried at room temperature $25-30{ }^{\circ} \mathrm{C}$ for $20-24$ hours, after which the films were removed from the dishes and placed in polyethylene bags and kept in the refrigerator [7].

How to Make Labneh: Labneh was manufactured in the laboratory using full fat cow's milk, where it was thermally treated at $90^{\circ} \mathrm{C}$ for five minutes in a water bath and then cooled to a temperature of $45^{\circ} \mathrm{C}$ and inoculated with the prepared milk starter in the form of dry cells (Lactobacillus bulgaricus and Streptococcus thermophiles) At a rate of $3 \%$ and incubated at $42{ }^{\circ} \mathrm{C}$ for 3-4 hours, after complete coagulation, the curd was left to cool at room temperature for an hour, after which it was placed in the fridge at a temperature of $5^{\circ} \mathrm{C}$ for 24 hours, after that it was placed in a clean cloth bag adding $0.5 \%$ salt to it and placed in the refrigerator at $5{ }^{\circ} \mathrm{C}$ for 22 hours. After that, the filter bag was emptied into a clean plastic container and stored at $6{ }^{\circ} \mathrm{C}$ in the refrigerator [8]. 
Packaging of Labneh Samples: Labneh samples were cut in a rectangular shape and weighing 50 gm for the sample to ensure that the envelopes are completely contained in the samples and encapsulated with gelatin films, then stored in the fridge until the tests are carried out and according to the suggested time periods.

The Microbial Tests for the Labneh: the total bacterial numbers and the number of yeasts and molds in the labneh samples were estimated using the spreading method, according to what Frank and Yousef mentioned [9], Harrigan and McCence [10] were followed to estimate the numbers of proteolytic and lipolytic bacteria.

Statistical Analysis: The results of the experiments were analyzed using the Linear Model General within the ready-made statistical program SAS [14] to study the effect of factors on the complete random design of the CRD. Duncan test [15] was also performed to determine the significance of the differences between the averages of the factors affecting the traits studied at (0.05) level.

\section{Results and Discussion}

Total Number of Microbial Content: Table (1) shows the effect of treatment with gelatin or gelatinous membranes with added GBE or nanomaterials in comparison with the control sample of the labneh on the total number of microbial content, the results indicated that the number of total microbial content at the beginning of the storage period( one day) for treatments T1, T2, T3 , T4, T5, T6, T7 were decreased after loading the labneh with the different membranes at 11.62, 11.55, 9.30, 9.25, 9.32, 8.57, and $8.50 \mathrm{log} / \mathrm{g}$, respectively. With the prolongation of the storage period, the gradual increase in the total microbiological numbers of all treatments occurred, it reached the highest numbers at the time of 14 days, as the results of the statistical analysis showed that the above transactions had significant differences in the rate of increase in the microbiological numbers to 11.32, $11.40,11.27,10.06,9.93 \mathrm{log} / \mathrm{g}$, respectively, compared with the two control samples T1, which was $15.58 \mathrm{log} / \mathrm{g}$ and T2 $13.47 \mathrm{log} / \mathrm{g}$. Upon following the increase in the total microorganism's numbers to the end of the storage period, it was found that treatment T7 was better in terms of its lower microbiological content compared with the two control samples T2 and T1.

Table (1). Effect of different treatments on the number of total microbial content in labneh coated with gelatin.

\begin{tabular}{|c|c|c|c|}
\hline \multicolumn{3}{|c|}{$\begin{array}{l}\text { The total number of microbial content in the sample of labneh } \\
\qquad \log / g\end{array}$} & \multirow{2}{*}{$\underset{* * *}{\text { Treatment }}$} \\
\hline 14 days & 7 days & 1 day & \\
\hline $15.58 \pm 0.66^{\mathrm{a}}$ & $14.77 \pm 0.23^{\mathrm{a}}$ & $11.62 * \pm 0.88^{a * *}$ & $\mathrm{~T} 1$ \\
\hline $13.47 \pm 0.35^{b}$ & $13.25 \pm 0.18^{b}$ & $11.55 \pm 0.41^{\mathrm{a}}$ & $\mathrm{T} 2$ \\
\hline $11.32 \pm 0.37 \mathrm{c}$ & $10.57 \pm 0.13^{c}$ & $9.30 \pm 0.71^{b}$ & $\mathrm{~T} 3$ \\
\hline $11.40 \pm 0.77^{\mathrm{c}}$ & $10.55 \pm 0.31^{\mathrm{c}}$ & $9.25 \pm 0.54^{b}$ & $\mathrm{~T} 4$ \\
\hline $11.27 \pm 0.19^{\mathrm{c}}$ & $10.42 \pm 0.66^{\mathrm{c}}$ & $9.32 \pm 0.83^{b}$ & $\mathrm{~T} 5$ \\
\hline $10.06 \pm 0.48^{\mathrm{d}}$ & $9.83 \pm 0.22^{d}$ & $8.57 \pm 0.74^{c}$ & T6 \\
\hline $9.93 \pm 0.28^{\mathrm{d}}$ & $9.69 \pm 0.33^{\mathrm{d}}$ & $8.50 \pm 0.19^{c}$ & $\mathrm{~T} 7$ \\
\hline
\end{tabular}

*The numbers in the table are an average of three replications.

**The different letters in one column indicate significant differences at the level of $(\mathrm{P}<0.05)$.

$* * * \mathrm{~T} 1=$ control, $\mathrm{T} 2=$ gelatin, $\mathrm{T} 3=$ gelatin $+\mathrm{GBE}, \mathrm{T} 4=$ gelatin $+\mathrm{CHNPS}, \mathrm{T} 5=$ gelatin $+\mathrm{TiO}_{2} \mathrm{NPS}, \mathrm{T} 6=$ gelatin $+\mathrm{GBE}+\mathrm{CHNPS}, \mathrm{T} 7=$ gelatin $+\mathrm{GBE}+\mathrm{TiO}_{2} \mathrm{NPS}$.

These results are consistent with what Al-Hadidi found [14], who indicated that the total numbers of bacteria in Labneh ranged between 10.5-11.32 $\mathrm{log} / \mathrm{g}$. The increase in the microbial numbers in treatment $\mathrm{T} 1 \mathrm{more}$ than in treatment T2 may be due to the lack of encapsulation of the labneh and its exposure to the atmosphere directly. The reason for the decrease in the total bacterial numbers in the treatment is attributed to the interfering action of each of the gelatin membranes, as it contributes to preventing the proliferation of the aerobic organisms by 
preventing the entry of oxygen that is essential for the growth of aerobic regeneration, which led to a reduction in their numbers or prolongation of the Lag phase and thus reducing the growth rates of bacteria. Oxygen has an important role in controlling the growth of aerobic organisms through the great role in the water activity (aw) necessary for the activity of these microbiology as some organisms depend on oxygen concentrations to provide a minimum level of water activity [15]. On the other hand, the effectiveness of the film-coated GBE against bacterial species (positive and negative Gram stain) is due to the presence of the phenolic compounds that the extract contains, especially catechins [17]. The reason for the low number of microorganisms may also be attributed to the role of nanoparticles in reducing or inhibiting the growth of microorganisms that inhibit cellular enzymes and DNA by binding to electron-giving groups such as carboxylate, amides, indoles, hydroxyls, and sulfur groups, as well as it has the ability to creates holes in the bacterial cell walls, leading to increased permeability and cell death [17]. The inhibition ability of $\mathrm{TiO}_{2}$ NPs and ChNPs could be due to the interaction of the surface of the molecules with water when exposed to ultraviolet rays, which leads to the release of free radicals such as $\mathrm{OH}$ and $\mathrm{O}_{2}$, which represent a high oxidative power that leads to the destruction of bacteria [18].

Lipolytic Bacteria: Table (2) shows the effect of adding different coatings (gelatin films, gelatinous films with added GBE, nanomaterials) on the total number of lipolytic bacteria in the labneh samples. The results indicated that the total number of bacteria at the beginning of the storage period (the first day) for treatments (T1, T2, T3, T4, T5, T6, and T7) did not show any growth of bacteria. With the prolongation of the storage period, the gradual increase in the number of bacteria occurred for all treatments, as the highest bacterial number was recorded on the fourteenth day, the results of the statistical analysis showed in the above treatments the presence of significant differences in the rate of increase of bacterial numbers to 4.87, 4.31, 4.32, 4.25,4.17, 3.08 $\mathrm{log} / \mathrm{g}$, respectively, compared with the control sample T1, which was $6.89 \mathrm{log} / \mathrm{g}$. Upon following the increase in the bacterial numbers until the end of the storage period, it was found that treatment $\mathrm{T} 7$ was the best in terms of its lower bacterial content compared with the control sample T1. The reason for the presence of the number of lipolytic bacteria can be attributed to the high percentage of lipid resulting from the low moisture content as well as the changes occurring in the labneh samples during storage. These results are consistent with the findings of Mocan et al. [19] who indicated the role of the GB plant in reducing the numbers of lipolytic bacteria and attributed the reason for this to the content of active compounds that inhibit the growth of microorganisms. These results also agree with what Albertos et al. [20] have indicated that the manufactured edible films consisting of gelatin with the addition of the alcohol extract of olive leaves as an anti-microorganism and anti-oxidant substance used in food preservation significantly reduced the growth of lipolytic bacteria as the inhibitory activity increased by increasing the concentration in its composition. These results also agree with the study of Zhang and Chen [21] who indicated the role of nanoparticles in inhibiting the growth of lipolytic bacteria and attributed this to the fact that these particles carry a positive charge while microorganisms have a negative charge on their outer wall, which results in an electromagnetic attraction between microorganisms, nanoparticles cause oxidation and finally kill these organisms or through increasing the permeability of the membrane, which leads to the entry of materials from the external environment, which results in an imbalance of the osmosis pressure, at the same time the cytoplasmic content is destroyed and then the cell dies.

Proteolytic Bacteria: Table (3) shows that in all samples of non-encapsulated labneh and coated with gelatin or gelatinous membranes, ChNPs and $\mathrm{TiO}_{2} \mathrm{NPs}$ at the first day no growth of proteolytic bacteria was shown. With the continuation of the storage of the labneh samples until the seventh day, it was found that the proteolytic bacteria in the samples T3, T4, T5, T6, T7 had growth rates of 1.55, 1.41, 1.34, 1.26, $1.15 \mathrm{log} / \mathrm{g}$, respectively, and a lower rate of bacterial numbers compared to the two treatment $\mathrm{T} 1, \mathrm{~T} 2$ that were at 2.08 and $1.89 \mathrm{log} / \mathrm{g}$ respectively. At the time of 14 days of storage at a temperature of $7 \stackrel{\circ}{\mathrm{C}}$, it was observed that the numbers of protein-degrading bacteria increased significantly, reaching the highest rate at the end of the storage period for the treatments, T4, T5, T6, T7 at 2.87, 2.53, 2.50, 2.32, $2.19 \mathrm{log} / \mathrm{g}$, respectively, compared to the highest growth rates of these bacteria in the two treatments, T1 and T2, which amounted to 3.00 and $3.22 \mathrm{l} / \mathrm{g}$, respectively. Treatment $\mathrm{T} 7$ proved to have the least increase in the numbers of proteolytic bacteria among all treatments compared to the control samples T2 and $\mathrm{T} 1$ at the end of the period storage. The results agreed with what Bonilla and Sobra [22] found, that the proteolytic bacteria did not show any growth in the first four days of storage, and the growth appeared after the tenth day. The results of this study also agree with the findings of Mocan et al. [19] that the alcoholic GBE has inhibitory activity against proteolytic bacteria, and it was found that this activity is due to the flavonoids and terpenoids. These results converged with what El-Sisi et al. [23] found, which stated that the number of proteolytic 
bacteria at growth rates reached $1.5-6.4 \mathrm{log} / \mathrm{g}$ during the specified storage periods. The reason for the low levels of proteolytic bacteria can be attributed to the role of $\mathrm{TiO}_{2} \mathrm{NPs}$, ChNPs added to Gelatinous films that have been shown to inhibit the growth of microorganisms.

Table (2). Effect of different treatments on the number of lipolytic bacteria in labneh coated with gelatin films.

\begin{tabular}{|c|c|c|c|}
\hline \multicolumn{3}{|c|}{$\begin{array}{l}\text { The total number of lipolytic bacteria of the labneh samples } \\
\qquad \log / g\end{array}$} & \multirow{2}{*}{$\underset{* * *}{\text { treatments }}$} \\
\hline 14 days & 7 days & 1 day & \\
\hline $\begin{array}{r}6.89 \\
\pm 0.06^{\mathrm{a}} \\
\end{array}$ & $\begin{array}{l}3.37 * \\
\pm 0.15^{\mathrm{a} * *}\end{array}$ & Nil & $\mathrm{T} 1$ \\
\hline $\begin{array}{c}4.87 \\
\pm 0.27^{b}\end{array}$ & $\begin{array}{c}2.12 \\
\pm 0.33^{\mathrm{b}}\end{array}$ & Nil & $\mathrm{T} 2$ \\
\hline $\begin{array}{r}4.31 \\
\pm 0.54^{\mathrm{b}} \\
\end{array}$ & $\begin{aligned} & 2.06 \\
\pm & 0.09^{\mathrm{b}}\end{aligned}$ & Nil & $\mathrm{T} 3$ \\
\hline $\begin{aligned} & 4.32 \\
\pm & 0.16^{\mathrm{b}}\end{aligned}$ & $\begin{aligned} & 2.00 \\
\pm & 0.33^{\mathrm{b}}\end{aligned}$ & Nil & $\mathrm{T} 4$ \\
\hline $\begin{aligned} & 4.25 \\
\pm & 0.25^{\mathrm{b}}\end{aligned}$ & $\begin{aligned} & 2.04 \\
& \pm 0.12^{\mathrm{b}} \\
&\end{aligned}$ & Nil & T5 \\
\hline $\begin{aligned} & 4.17 \\
\pm & 0.31^{\mathrm{b}}\end{aligned}$ & $\begin{aligned} & 2.06 \\
\pm & 0.07^{\mathrm{b}}\end{aligned}$ & Nil & T6 \\
\hline $\begin{aligned} & 3.08 \\
\pm & 0.11^{\mathrm{c}}\end{aligned}$ & $\begin{aligned} & 2.00 \\
\pm & 0.05^{\mathrm{b}}\end{aligned}$ & Nil & $\mathrm{T} 7$ \\
\hline
\end{tabular}

*The numbers in the table are an average of three replications.

**The different letters in one column indicate significant differences at the level of $(\mathrm{P}(0.05)$.

$* * * \mathrm{~T} 1=$ control, $\mathrm{T} 2,=$ gelatin, $\mathrm{T} 3=$ gelatin $+\mathrm{GBE}, \mathrm{T} 4=$ gelatin $+\mathrm{CHNPS}, \mathrm{T} 5=$ gelatin $+\mathrm{TiO}_{2} \mathrm{NPS}, \mathrm{T} 6=$ gelatin $+\mathrm{GBE}+\mathrm{CHNPS}, \mathrm{T} 7=$ gelatin $+\mathrm{GBE}+\mathrm{TiO}_{2} \mathrm{NPS}$.

Table (3). Effect of different treatments on the number of proteolytic bacteria in labneh coated with gelatin.

\begin{tabular}{|c|c|c||c|}
\hline \multicolumn{3}{|c|}{ The total number of proteolytic bacteria of labneh samples } & Log/ml \\
\hline $\mathbf{1 4}$ days & $\mathbf{7}$ days & 1 day & $* * *$ \\
\hline $\begin{array}{c}3.22 \\
\pm 0.05^{\mathrm{a}}\end{array}$ & $\begin{array}{c}2.08^{*} \\
\pm 0.23^{\mathrm{a} *}\end{array}$ & $\mathrm{~T} 1$ \\
\hline $\begin{array}{c}3.00 \\
\pm 0.14^{\mathrm{b}}\end{array}$ & $\begin{array}{c}1.89 \\
\pm 0.33^{\mathrm{b}}\end{array}$ & $\mathrm{N}$ T2 \\
\hline $\begin{array}{c}2.87 \\
\pm 0.25^{\mathrm{c}}\end{array}$ & $\begin{array}{c}1.55 \\
\pm 0.17^{\mathrm{c}}\end{array}$ & Nil & $\mathrm{T} 3$ \\
\hline $\begin{array}{c}2.53 \\
\pm 0.00^{\mathrm{c}}\end{array}$ & $\begin{array}{c}1.41 \\
\pm 0.08^{\mathrm{c}}\end{array}$ & Nil & $\mathrm{T} 4$ \\
\hline $\begin{array}{c}2.50 \\
\pm 0.03^{\mathrm{c}}\end{array}$ & $\begin{array}{c}1.34 \\
\pm 0.05^{\mathrm{c}}\end{array}$ & Nil & $\mathrm{T} 5$ \\
\hline $\begin{array}{c}2.32 \\
\pm 0.09^{\mathrm{d}}\end{array}$ & $\begin{array}{c}1.26 \\
\pm 0.13^{\mathrm{d}}\end{array}$ & Nil & $\mathrm{T} 6$ \\
\hline $\begin{array}{c}2.19 \\
\pm 0.20^{\mathrm{d}}\end{array}$ & $\begin{array}{c}1.15 \\
\pm 0.11^{\mathrm{d}}\end{array}$ & Nil & $\mathrm{T} 7$ \\
\hline
\end{tabular}

*The numbers in the table are an average of three replications. 
**The different letters in one column indicate significant differences at the level of $(\mathrm{P}(0.05)$.

$* * * \mathrm{~T} 1=$ control, $\mathrm{T} 2=$ gelatin, $\mathrm{T} 3=$ gelatin $+\mathrm{GBE}, \mathrm{T} 4=$ gelatin $+\mathrm{CHNPS}, \mathrm{T} 5=$ gelatin $+\mathrm{TiO}_{2} \mathrm{NPS} \mathrm{T} 6=$ gelatin $+\mathrm{GBE}+\mathrm{CHNPS}, \mathrm{T} 7=$ gelatin $+\mathrm{GBE}+\mathrm{TiO}_{2} \mathrm{NPS}$.

Yeasts and Molds: It is noticed from the results of Table (4) that no growth of molds and yeasts appeared in all transactions at the beginning of the storage period (the first day) up to the seventh day, with the continuation of storage labneh samples until the end of the storage period (day 14), a growth of molds and yeasts was observed and these numbers were recorded:1.15, 1.09, 1.09, 0.85, $0.73 \mathrm{log} / \mathrm{g}$ for the parameters T3, T4, T5, T6, and T7 respectively compared to the two control treatments $\mathrm{T} 2$ and $\mathrm{T} 1$ which were at 1.81 and $1.60 \mathrm{log} / \mathrm{g}$, respectively. When all the treatments were compared to each other, the priority for treatment $\mathrm{T} 7$ was in terms of the decrease in its microbial content, as the logarithmic growth rate was $0.73 \mathrm{log} / \mathrm{g}$. Al-Tahiri [24] mentioned that when making a balance in microbiological examinations between the labneh manufactured under sterile conditions (modern methods of manufacturing) and the labneh manufactured by The rural traditional way. He noticed that the labneh manufactured by modern methods was free of yeasts and molds, while the rural labneh contained $5 \times 105 \mathrm{cfu} / \mathrm{ml}$ yeasts and molds. The reason for the significant difference between the two comparison samples and the other treatments can be attributed to the use of antimicroorganism agents with these envelopes, as it contributed to limiting the growth of molds compared to the treatments that did not use these agents, as the presence of GB and active nanocomposites in these gelatinous membranes proved their ability to inhibiting or destroying the hypha and spores of molds [25]. The reason for the inhibition may also be due to the role of nanoparticles in reducing or inhibiting the growth of yeasts and molds through their effect on the cell wall and increasing its permeability, inhibition of respiratory enzymes and stopping the multiplication of genetic material [3]. to compare the results of this study in terms of using the plant extract as a natural preservative with the industrial preservatives used in the dairy industry, we note through what Hachana and Rebhi (2019) [26] presented that the traditional preservatives such as potassium dichromate and pronopol, can be used to store raw milk samples for physicochemical analyses for up to 3 days at $25^{\circ} \mathrm{C}$ temperature, without any significant changes in chemical composition, freezing point, electrical conductivity, and total aerobic mesophilic flora. While when using natural materials (plant extract), we noticed that the labneh retained its properties and strength for more than 10 days.

Table (4). Effect of different treatments on the number of yeasts and molds in labneh coated with gelatin films.

\begin{tabular}{|c|c|c|c|}
\hline \multicolumn{2}{|c|}{ The total number of yeasts and molds in the labneh samples } & treatments \\
log/g & 1 day \\
\hline $\mathbf{1 4}$ days & 7 days & Nil & T1 \\
\hline $\begin{array}{c}1.81^{*} \\
\pm 0.15^{\mathrm{a} *}\end{array}$ & Nil & Nil & T2 \\
\hline $\begin{array}{c}1.60 \\
\pm 0.21^{\mathrm{b}}\end{array}$ & Nil & Nil & T3 \\
\hline $\begin{array}{c}1.15 \\
\pm 0.25^{\mathrm{c}}\end{array}$ & Nil & Nil & $\mathrm{T} 4$ \\
\hline $\begin{array}{c}1.09 \\
\pm 0.17^{\mathrm{c}}\end{array}$ & Nil & Nil & $\mathrm{T} 5$ \\
\hline $\begin{array}{c}1.09 \\
\pm 0.08^{\mathrm{c}}\end{array}$ & Nil & Nil & T6 \\
\hline $\begin{array}{c}0.85 \\
\pm 0.03^{\mathrm{d}}\end{array}$ & Nil & Nil & T7 \\
\hline $\begin{array}{c}0.73 \\
\pm 0.13^{\mathrm{d}}\end{array}$ & Nil & & \\
\hline
\end{tabular}

*The numbers in the table are an average of three replications.

**The different letters in one column indicate significant differences at the level of $(\mathrm{P}(0.05)$.

$* * * \mathrm{~T} 1=$ control, $\mathrm{T} 2=$ gelatin, $\mathrm{T} 3=$ gelatin $+\mathrm{GBE}, \mathrm{T} 4=$ gelatin $+\mathrm{CHNPS}, \mathrm{T} 5=$ gelatin $+\mathrm{TiO}_{2} \mathrm{NPS} \mathrm{T} 6=$ gelatin

$+\mathrm{GBE}+\mathrm{CHNPS}, \mathrm{T} 7=$ gelatin $+\mathrm{GBE}+\mathrm{TiO}_{2} \mathrm{NPS}$. 


\section{Conclusions}

$>$ The nanoparticles of each of chitosan (ChNPs) and titanium dioxide nanoparticles $\left(\mathrm{TiO}_{2}\right)$ have a moderate inhibitory capacity against the bacterial species that cause food poisoning, this inhibitory increases when the alcoholic extract of GBE is added to it.

$>$ The gelatinous membranes loaded with particles of ChNPs, $\mathrm{TiO}_{2} \mathrm{NPs}$ and GBE reduced the number of bacteria and molds that cause deterioration of the labneh and reduced the changes in its chemical properties.

$>$ The nanotitanium was better than chitosan in reducing the total number of bacteria

$>$ The alcoholic GBE has anti-bacterial and antifungal effects.

\section{References}

[1] Alshehabi, M. Faten hamed, F., Abou-ghorrah, S. "Effect of the Type of the Starter and Inoculation Rate on the Characteristics of Labneh Made in a Direct Method Compared with the Traditional Labneh," Syrian Journal of Agricultural Research, vol.2, no.2, pp. 55-68. 2015.

[2]Hassabo, R. M." Chemical Composition and Quality of Labneh Contaning Palm Oil Made by Frequent Homogenizer, J. Food and Dairy Sci., Mansoura Univ., vol. 8, no. 11, pp. 431-434, 2017.

[3] Nahar,A.K. "Chemical and biological evaluation of some synthesized nanoparticles loaded on gelatin for use as a membrane in the preservation of soft cheese, $\mathrm{PhD}$ thesis, Tikrit University, College of Agriculture, 2020.

[4] Kulczyński, B. and Gramza-Michałowska, A. "Goji Berry (Lycium barbarum): Composition and Health Effects - a Review," Pol. J. Food Nutr. Sci., vol. 66, no. 2, pp. 67-75. DOI: 10.1515/pjfns-2015-0040, 2016.

[5] Ali, Aisha Hussein, "The inhibitory activity of nanoparticles of zinc oxide, titanium dioxide and craviola extract against bacterial species isolated from different sources of infection," $\mathrm{PhD}$ thesis, Tikrit University, College of Education for Pure Sciences, 2017.

[6] Jennifer, K. and Peter, V., "Nanotechnology in agriculture and food production:Anticipated applications, "Washington, DC: Woodrow Wilson International Center for Scholars, Project on Emerging Nanotechnologies, 2006.

[7]Chan, E. W. C., Lim, Y. Y. and Chew, Y. L, "Antioxidant activity of Camellia sinensis leaves and tea from a lowland plantation in Malaysia," Food chemistry, vol.102, no.4, pp. 1214-1222, 2007.

[8] De Carvalho, R. A. and Grosso, C. R., "Characterization of gelatin based films modified with transglutaminase, glyoxal and formaldehyde," Food hydrocolloids, vol.18 no. 5, pp. 717-726, 2004.

[9] Al-Kadamany, E., Khattar, M. Haddad, Th. and Toufili, I., "Determination of Shelf life of concentrated yoghurt produced by in-Bag straining of set yogurt using hazard analysis," Journal of Dairy Science., vol. 85, pp.1023-1030, 2002.

[10] Frank, J. F. and Yousef, A. E., "Tests for groups of microorganisms. In: Standard Methods for the Examination of Dairy Products." Wehr, H. M. and Frank, J.F (Ed). 17th edition. Washington, American Public Health Association. (Chapter 8). pp.187-226. 2004.

[11] Harrigan, W. F. and McCance, M. E., "Laboratory method in food and dairy microbiology," Acadmic press INC. New York. U.S.A. 1976.

[12] SAS, Statistical Analysis System, User's Guide. Statistical. Version 9.1th ed. SAS. Inst. Inc. Cary. N.C. USA. 2012.

[13] Duncan, D.B., "Multiple range and multiple "F" test," Biometric, vol.11, pp.1-42. 1955.

[14] Al-Hadidi, Lamis Thamer," Manufacture of therapeutic labneh by various methods using Lactobacillus acidophilus and Lactobacillus casei. M.S. thesis, University of Baghdad, College of Agriculture, 2009.

[15] Ouattara, B., Simard, R.E., Piette, G., Bégin, A., Holley, R.A., "Inhibition of surface spoilage bacteria in processed meats by application of antimicrobial films prepared with chitosan," Internat J Food Microbiol, vol. 62, pp.139-148, 2000.

[16] Suhaila, Sharwana, "Separation and identification of the flavonide secondary metabolite products of the plant Lycium arabicum.L.," M.S. thesis, Faculty of Sciences, University of Mentouri Constantine, Republic of Algeria, 2007.

[17] Haghi, M., Mohammed, H., Mohammed, B. J., Saman, S., Mohammed, K. F., Farzad, S. and Marjan, G, "Antibacterial effect of $\mathrm{TiO}_{2}$ nanoparticles on pathogenic strain E. coli." International Journal of Advanced Biotechnology and Research, vol.3, no.3, pp.621-624, 2012.

[18] Morsy, M., Mostafa, K., Amyn, H., El-Ebissy, A., Salah, A. and Youssef, M., "Synthesis and Characterization of Freeze Dryer Chitosan Nanoparticles as Multifunctional Eco-Friendly Finish for Fabricating Easy Care and Antibacterial Cotton Textiles," Egypt. J. Chem. vol.62, no.7, pp.1277- 1293, 2019. 
[19] Mocan, A., Vlase, L., Vodnar, D., Bischin, C., Hanganu, D., Gheldiu, A., Oprean, R., Dumitrescu, R. and Crișan, G., "Polyphenolic Content, Antioxidant and Antimicrobial Activities of Lycium barbarum L. and Lycium chinense Mill, Leaves," Molecules, vol. 19, no. 7, https://doi.org/10.3390/molecules190710056 [Accessed July 2014].

[20] Albertos, I., Avena-Bustillos, R. J., Martín-Diana, A. B., Du, W. X. Rico, D. and McHugh T. H., "Antimicrobial Olive Leaf Gelatin films for enhancing the quality of cold-smoked Salmon," Food Packaging and Shelf Life, vol. 13, pp. 49-55. 2017.

[21] Zhang, H. and Chen, G., "Potent antibacterial activities of $\mathrm{Ag} / \mathrm{TiO} 2$ nanocomposite powders synthesized by a one-pol sol-gel method," Environ Sci Technol, vol. 34, no. 8, pp. 2905-2910, 2009.

[22] Bonilla, J. and Sobral, P. J., "Gelatin-chitosan edible film activated with Boldo extract for improving microbiological and antioxidant stability of sliced Prato cheese." International Journal of Food Science and Technology, vol. 54, no. 5, pp. 1617-1624, 2019.

[23] El-Sisi, A. S.; Gapr, A. M. and Kamaly, K. M., "Use of chitosan as an edible coating in RAS cheese," Biolife, vol. 3, no. 2, pp. 564-570, 2015.

[24] AL-Tahiri, R., "Acomparison on microbial conditions between treditional dairy products sold in karak \& same products produced by modern dairies," Pakistan J. Nutr, vol. 4, no. 5, pp. 345-348, 2005.

[25] D'Amato, D. and Sinigaglia, M., "Antimicrobial agents of microbial origin: Nisin. Application of alternative food-preservation technologies to enhance food safety and stability," 1st edn. Bentham Science, USA, 83-91, 2010.

[26] Y. Hachana and A. Rebhi, "Comparative Study Between Conventional Preservatives and Methylene Blue on Chemical and Bacteriological Composition of Raw Milk," Asian J. Dairy Food Res, vol. 38, no. 2, pp. 87-92, 2019. 